\title{
ON DEATH, LOSS, MYSTERY, AND OTHER EXISTENTIAL CONCERNS IN COLM TÓIBÍN'S THE BLACKWATER LIGHTSHIP (1999) ${ }^{1}$
}

\author{
Mayron Estefan Cantillo Lucuara \\ Universitat de València \\ Mayron.Cantillo@uv.es
}

\begin{abstract}
Equipped with dense philosophical terminology and based on an insightful review by Richard Canning, this article proposes a new reading of Colm Tóibín's The Blackwater Lightship, meant to shed some light on the complex portrayal of Helen O'Doherty with the theoretical help of what is broadly known as existentialism. Martin Heidegger, Karl Jaspers, Jean Paul Sartre, Gabriel Marcel and other contemporary philosophers — associated in one way or another with the existentialist schools and traditions - are all invoked and reinterpreted in direct dialogue with the novel under consideration for the sole purpose of applying such elucidative notions as Geworfenheit, Sein-zum-Tode, limit situation, bad faith or mystery to the quandaries and challenges that Helen encounters in the face of her brother's imminent death. The outcomes of such a dialogue reveal that The Blackwater Lightship constitutes a profoundly existential novel.
\end{abstract}

KEYwORDS: death, loss, mystery, existentialism, Colm Tóibín.

\section{RESUMEN}

Equipado con abundante terminología filosófica y basado en una reveladora recensión de Richard Canning, el presente artículo propone una nueva lectura de The Blackwater Lightship de Colm Tóibín, orientada a arrojar luz sobre la compleja caracterización

${ }^{1}$ Some of the ideas propounded in this paper were tentatively addressed in a modest presentation I delivered at the International Conference on Contemporary Narratives in English, organized by the University of Zaragoza in 2015 . 
de Helen O’Doherty con el respaldo teórico de lo que se conoce genéricamente como existencialismo. Martin Heidegger, Karl Jaspers, Jean Paul Sartre, Gabriel Marcel y otros pensadores contemporáneos — vinculados de una forma u otra con las escuelas y tradiciones existencialistas - se reúnen en este estudio y se reinterpretan en diálogo directo con la novela en cuestión con el propósito último de aplicar nociones tan esclarecedoras como Geworfenheit, Sein-zum-Tode, situación límite, mala fe o misterio a los problemas y desafíos que arrostra Helen ante la inminente muerte de su hermano. Los resultados de dicho diálogo revelan que The Blackwater Lightship constituye una novela profundamente existencialista.

Palabras Clave: muerte, pérdida, misterio, existencialista, Colm Tóibín.

\section{INTRODUCTION}

Colm Tóibín is a distinguished name in contemporary Irish fiction. His written production comprises eight novels (The South, The Heather Blazing, The Story of the Night, The Blackwater Lightship, The Master, Brooklyn, The Testament of May, and Nora Webster), two collections of short stories (Mothers and Sons and The Empty Family), and a large array of non-fiction essays, editions, and even travel books. Many of these works have earned him such notable prizes and honours as the 2004 Stonewall Book Award, the 2006 International IMPAC Dublin Literary Award, the 2011 Irish Pen Award, and many others. The reason behind these laurels may reside, according to Waterman (2012), in Tóibín's masterly ability to explore "the mixed motives and tacit exchanges and torn senses of identity that make us who we are, hold things together, [and] tear them apart." For his work, argues Waterman, seems to constitute a laboratory where one can investigate "human uncertainties, frailties, exploitations, love, carelessness and all of the multifarious things that" define our existence.

One of such laboratories is The Blackwater Lightship (1999), an elegiac novel that centres on the well-rounded character of Helen O'Doherty, a school principle whose life unfolds stably and monotonously until the fateful day when she is informed that her brother Declan is dying of AIDS. This piece of news, although merely based on the words of a stranger, bursts her world asunder. Her stability collapses as death becomes a looming threat, a reminder of her traumatic past, and a unifying force. As soon as she sees her brother in the hospital, she realises his last breath is impending. To fulfil his wishes for familial reunion, Helen visits her mother and grandmother after many years of solid distance. The past surfaces up with bitter memories, fermented resentments, painful losses, and hard frictions between the three women. However, in honour and respect of Declan's will, the whole family reunites, re-evaluates their memories, settles their differences through sincere and profound dialogue, and achieves reconciliation. The ending is strangely happy: Declan loses his battle against AIDS, but his family restores their mutual love.

The reception that The Blackwater Lightship has enjoyed is highly considerable and mostly favourable. As soon as the novel was released in 1999, it received a fairly positive review from British intellectual Terry Eagleton and found an outstanding place in the 
Booker Prize shortlist. Five years later, in 2004, the Hallmark Hall of Fame adapted it into a film under the direction of John Erman, with Shane Connaughton as the screenwriter, and with Gina McKee as the main character (Helen). The academic appraisal came afterwards: the novel has been analysed in light of such dual perspectives as absence and trauma, tradition and modernity, post-nationalism and cultural revisionism, homosexuality and AIDS, deterritorialisation and the problem of home, and even marine imagery. ${ }^{2}$ However, given that none of these points of view has allowed for a systematic study of the existential depths of Tóibín's novel, which seem to me fundamental and transparent, I aim to devote the present article to exploring them. My starting point is a fairly basic definition of existentialism: according to Michelman (2010), it can be understood as an "attempt to provide a philosophical account of the distinctive features of human existence," such as its "lived awareness of time or [its] relationship to death" (1). It is, in fact, the very question of mortality that, as I shall demonstrate, dominates the human landscapes of The Blackwater Lightship and renders it especially susceptible of an existential reading.

Such susceptibility is what Richard Canning (1999) arguably perceived in his laudatory review for The Independent, where he defined the novel as "a mature, philosophical work." I concur with him: The Blackwater Lightship is so intense and dense with psychological complexity, metaphysical cogitation, and emotional profundity, that it lends itself to an indepth analysis through the prism of those philosophical doctrines commonly identified under the broad term of existentialism. For this reason, Martin Heidegger, Jean Paul Sartre, Gabriel Marcel and other contemporary thinkers will all be convened in what follows for the sole purpose of illuminating and accounting for the metaphysical issues fictionalised by Colm Tóibín in the novel under scrutiny.

\section{THROUGH THE LENSES OF EXISTENTIALISM}

As I have previously suggested, the philosophical issues underlying The Blackwater Lightship derive chiefly from the thorough exploration of the undiscovered country of death, as well as other arcane territories like those of lost love, melancholy, guilt, abandonment, silence, and trauma. In the midst of these desolate humanscapes is Helen O'Doherty, an Irish woman whose life, initially untroubled and rather humdrum, plunges suddenly and convulsively into a radical state of thrownness - in Heidegger's words, Geworfenheit. I apply this term here in a broad literal sense, not just limited to the notion of the arbitrary convergence between the past and the present in our being-in-the-world, ${ }^{3}$ but rather in connection with how the others — the essential constituents of our Mitsein — and their own

\footnotetext{
${ }^{2}$ As it is not possible to revise and assess each and every article addressing these issues for reasons of space and pertinence, I refer the interested reader to Walshe (2008:115-130), Matthew (2008:19-32), Harte (2010:333-349), Costello-Sullivan (2012:123-154), Carregal (2012:5-6), and Yebra (2014:97-102).

${ }^{3}$ Generally speaking, this notion is, as Michelman explains (2010), "meant to highlight the way one is cast into one's situation without having chosen it, and perhaps to evoke the fortuitous character of existing in a particular place and time" (313). To my mind, such fortuity entails accepting the capricious grounds of one's own existence, as well as the vicissitudes that the Other brings to one's life.
} 
facticities interfere in our life, ${ }^{4}$ becoming part of our givens and many a time throwing us into new, disruptive situations that reveal our inherent condition of fallen creatures, always exposed to contingency. Helen falls prey to this particular form of thrownness: after a joyful celebration of the end of the school year with her family and friends, she is abruptly ejected into an unexpected plight. It is Paul, a friend of her brother's, who dynamites her normal life with a devastating piece of news: Declan, her gay brother, is dying of AIDS in hospital.

The opening atmosphere of enjoyment clashes starkly with the dooming fall that Paul instigates in Helen's ordinary existence — a fall into the spiritual and physical contemplation of Declan's agony. The stark clash aptly intimates how indiscriminately and randomly the world can fluctuate from conventional happiness to utter sorrow. Helen's discovery of her brother's fatal condition comes as a complete surprise, with no anticipation and no foreconsciousness of finitude. The permanent potentiality of death takes her aback as though it were something alien to life - in communion with what Karl Jaspers understands as positivism. ${ }^{5}$ It seems that, before the convulsive news, Helen simply took no notice of the truism of mortality, sliding her life in the fragile fullness of monotony, oblivious to her traumatic past and unprepared for any terminal eventuality. In a word, she was ordinarily inauthentic, alienated, impersonal, and next to the stasis of a being-in-itself - far from the vital plenitude that characterises the Heideggerian Dasein with all its resoluteness, lucid mindfulness, individuality, and openness towards death.

However, with the sudden arrival of Paul's news, Helen experiences a radical break in her life system. Her everyday structures of being collapse. Her normality suspends. She enters into a critical phase that may well be compared to what Heidegger calls a truth event. ${ }^{6}$ Jaspers would probably refer to it as a limit situation (Grenzsituation), one that dislocates us, banishes us from our comfort zones, plays havoc with our day-to-day protocols of existence, threatens our sense of selfhood, challenges our understanding of the world, demands new cognitive and behavioural patterns of resolution, and thus causes high levels of anxiety. ${ }^{7}$ In Helen's case, it is her potential brotherlessness - Declan's impending death — that confronts her with such a situation. To her eyes, hitherto used to watching her life unfold passively, mortality is no longer an alien phenomenon that only befalls others: it has become personalised through her brother's fading body. Death has adopted Declan's face, which

\footnotetext{
${ }^{4}$ In relation to the notion of thrownness, I also adhere to Sartre's understanding of facticity, which "denotes the givens of our situation such as our race and nationality, our talents and limitations, the others with whom we deal as well as our previous choices" (Flynn 2006:65-66). In light of this definition, the idea of thrownness may be associated not just with one's own fortuitous position in the world, but also with the inescapable interference of the Other in one's life.

${ }^{5}$ As Gray points out (1951), Jaspers considers that one of the most common ways of ignoring the onerous truth of mortality consists in adopting, as Helen seems to have done, the Epicurean and positivistic attitude of downplaying and externalising death as an experience that one never feels or lives due to the mere fact that "While I am, death is not, and when death is, I am not" (122).

${ }^{6}$ I take this notion from Luchte (2008), who explains that, according to Heidegger, "we can only know our own self when it has been resisted, broken or has encountered a limit-situation, via which each finds herself in her truth. Normality suspends [...] with an eclipse of the sun, an earthquake, a flood, the death of another —a truth event" (29).

${ }^{7}$ For Karl Jaspers, limit situations include "experiences of death, suffering, struggle, guilt, and chance, which in their incomprehensibility may provoke deep existential self-transformation," for through them "we transcend our mundane selves and enter into" an authentic mode of existence (Michelman 2010:214).
} 
Helen is inevitably bound to encounter - face to face- with stoicism. She is to develop an intentional consciousness of being-towards-her-brother's-death. By this phrase I do not exactly denote what Heidegger understands as Sein-zum-Tode: for while his thanatological conception is predicated upon a marked individualism, ${ }^{8} \mathrm{I}$ prefer to view finitude as a fundamentally relational and social experience in line with Critchley (2002):

death is first and foremost experienced as a relation to the death or dying of the other and others, in Being-with the dying in a caring way, and in grieving after they are dead [...] With all the terrible lucidity of grief, one watches the person one loves — parent, partner or child — die and become a lifeless material thing. That is, there is a thing - a corpse - at the heart of the experience of finitude. This is why I mourn [...] death and finitude are fundamentally relational, [...] constituted in a relation to a lifeless material thing whom I love and this thing casts a long mournful shadow across the self (169-170).

As a long mournful shadow, Declan's potential demise intrudes into Helen's world and shatters her fixed conventions of living, exposing her to the naked truth of human perishability and casting her into a tragic state of what Stolorow (2011) calls being-towardloss, which equates to what I have phrased as Helen's being-towards-her-brother's-death. The original Heideggerian term has no bearing in this context, mainly because it is not Helen's own-most mortality that preoccupies Tóibín's novel: what is at stake is her relation to Declan's passing — his traumatic disappearance from his sister's life or, in other words, the fragmentation of the affective fabric of her Mitsein. Stolorow (2014: 38) provides a clear description of the impact of loss that may be applicable to Helen's predicament: "Beingtoward-loss is [...] a Being-toward-the-death of a part of one's Being-in-the-world - a form of existential death. Traumatic loss shatters one's emotional world, and, insofar as one dwells in the region of such loss, one feels eradicated." In effect, as soon as Helen is briefed on her brother's AIDS-related afflictions, she seems to experience an instantaneous eradication from her coveted normalcy. As the omniscient narrator of the novel relates, "she felt an intense hostility" to Paul, the bearer of the bad news, whom she immediately perceives as a "heavy, ominous presence" (32), a menace to her quiet life. After leaving home and getting in her car to go to visit Declan in the hospital, she manifestly notices she is coming up against a crucial turning point and thus entertains a fleeting fantasy of escapism into her previous everydayness (Alläglichkeit), into an emptied alterity or, in Gray's words (1951), into impersonality:

Her first instinct was to run from the car, to watch for the next traffic lights and try to open the door and run to the pavement, and become the person entering a news-agent's shop or waiting for a bus, become anyone but the person she was in the car (33).

Two philosophical notions can adequately account for Helen's evasive demeanour, namely Gray's Geborgenheit and Sartre's bad faith. The former "connotes the delightful feeling of protectedness, the comfort of being hidden away or concealed from lurking

${ }^{8}$ In his view, death constitutes a possibility which is one's own-most and non-relational, i.e., it is unsharable —nobody can die one's death — and thus central to one's individuality: it is mortality — more than anything elsethat makes each human being an individual in his/her own right (Michelman 2010:112-113). 
dangers" (Gray 1951:117), and the illusory sense of security that Helen secretly wishes to recover by con-fusing herself with the anonymous Other - the mass of theyhood. It seems to her that the ontologically empty space where Heidegger locates das Man offers the solace that her broken self-hood cannot find within itself. ${ }^{9}$ Insensitive anonymity looks powerfully tantalising from her vulnerable position - confined in the car and destined to meet her brother's death sooner or later. I deliberately describe Helen's dreamt alterity as ontologically empty and insensitive on the basis of its implicit representation: for she envies an anonymous otherness that is hollow, depersonalised, and petrified. Her gaze, as if epitomising Sartre's early conception of intersubjectivity, ${ }^{10}$ objectifies "the person entering a news-agent's shop or waiting for a bus" (33), robs them of their individuality, transforms them into static beingsin-themselves, and thus dehumanises them. In so doing, what Helen genuinely intends to do is to project the image of her ideal self onto the others: she hankers after the emptiness, anonymity, and numbness that she instinctively attributes to the unknown people around her. As a possible way of escaping the succession of fateful events that Paul's visit heralds, she fantasises about dehumanising herself in favour of a false state of Geborgenheit. ${ }^{11}$

Such a fantasy is a form of what Sartre denominates bad faith, which designates the effort to flee the permanent human tension between facticity and transcendence and its subsequent anguish "by either collapsing the transcendence into facticity or volatilizing the facticity into transcendence" (Flynn 2006:134). The first option of the disjunction seems to pertain to Helen's situation in the car: in a momentary attempt to flee the tragic horizon that awaits her, she dreams of obliterating the possibility of her brotherless future, throwing herself into a petrified Mitsein and embracing a dehumanising form of social determinism that would ideally shape her self. Accordingly, she adopts "the attitude of bad faith which allows another subject to determine the identity to which [she wants] to conform" (Flynn 73). Far from aspiring to an individualised onto-poeisis, the type of subjectivity that Helen covets corresponds directly to her particular vision of alterity in the sense that, as I have already pointed out, she instinctively envies the de-authenticated existence of those who are outside her car and seems to contemplate the ephemeral yet heartfelt impulse of externalising herself, de-individuating herself, preferring to "become anyone but the person she was in the car"

\footnotetext{
${ }^{9}$ It appears to me that Helen's wish tallies with Heidegger's notion of das Man ("the one" or "the they"), which refers to the usual and average manner of human existence. For the German philosopher, "the ordinary trend of human life is to think and behave just like everyone else, conforming one's thoughts and actions to the expectations of the others" (Michelman 2010:110).

${ }^{10}$ In his masterpiece Being and Nothingness (1943), Jean Paul Sartre puts forward a fairly Hegelian theory of alterity that understands the Other as "another human consciousness who appears as alien to the self and is initially treated as an object to be subdued or destroyed" (Michelman 2010:253). This initial perception of the Other is instigated, according to the French thinker, through one's look or gaze, which objectifies, fixes, petrifies, and reduces the other's identity by robbing it of its freedom in such a way that it becomes "an element of facticity [one] can neither control nor simply ignore" (Michelman 2010:253).

${ }^{11}$ Later on, in her quest to reach this feeling and to solve her maternal conflicts, Helen also manifests a selfish desire to abandon her family one day and "appear at her mother's door asking to be taken in and forgiven" (120), thereby making the past re-emerge and inflicting the trauma she experienced as a girl upon her own children. Nevertheless, shortly after toying with such a desire, she herself dismisses it as "too dark and disloyal" (120) and suppresses it altogether.
} 
(33), refusing to witness her upcoming brotherlessness, and thus negating her being-towardsloss in favour of her social facticity and her ideal —emptied — identity.

Once in the hospital, before seeing her brother, Helen becomes fully aware of her germinal Unheimlichkeit (homelessness) as she realises she is no longer "in her own house, undisturbed" (35). ${ }^{12}$ She looks anxiously at her watch, which seems to function as an objective correlative connoting her desire to prevent her fixed temporality from disintegrating and to return to her inauthentic habits. Nonetheless, the fragmentation of her life-world is ongoing and irreversible. Towards the end of the conversation with Declan, who asks her to inform their mother and grandmother of his circumstances, Helen declares her feeling of real shock and tries to bring herself to literally actualise - to make a reality of - her plight: "I have to," she says, "keep convincing myself [...] that this is really happening. [...] He is dying" (38). The potentiality of losing her brother "became real and sharp," as well as "something new for her" (40). It is this newness - owing to the sudden unconcealment of death as a tangible possibility rather than a depersonalised fact - that tears up Helen's scheme of things and renders her incapable of immediate agency and resolution. Previously, "when she worried or was concerned, it was about things which could be solved or would pass," (40) but now her problem-solving logic proves useless in the face of what Gabriel Marcel would regard as a mystery in opposition to the notion of problem that bears readily upon Helen's state prior to her real shock. The French philosopher (1949) defines both concepts as follows:

A problem is something which I meet, which I find completely before me, but which I can therefore lay siege to and reduce. But a mystery is something in which I am myself involved, and it can therefore only be thought of as a sphere where the distinction between what is in me and what is before me loses its meaning and initial validity (117).

Put simply, Marcel distinguishes two types of questions which correspond to two different spheres or modes of existence: on the one hand, he identifies the problematic as the domain where life operates as an objective and technical organism, apparently bereft of ontological (transcendent) exigencies and merely assailed by dilemmas or obstacles that one can solve and surmount logically and practically; on the other hand, the French thinker observes that at odds with the sheer functionalism of the problematic is a realm, the mysterious, where existence becomes deeply subjective, involves the individual, transcends any objective reasoning, invalidates any technical solution, and thus leaves the involved subject alone, facing up to a personal ontological mystery which demands full recognition or induces evasion. ${ }^{13}$

Utilising Marcel's postulations, one could hold that, after leading a purely functional life of "things which could be solved," (40) Helen enters into the mysterious sphere of being

${ }^{12}$ I adhere to Heidegger's notion of Unheimlichkeit as the conceptualisation of the "feeling of not being at home that accompanies the experience of anxiety" (Michelman 2010:318), which can be identified with the sudden eradication from familiarity and everydayness that Helen undergoes when leaving her functional world and coming to terms with her brother's fate.

13 For a more detailed account of Marcel's distinction between the problematic and the mysterious, see Sweetman (1995:158-163), O'Callaghan (2009) or Treanor (2010). 
when she awakes to her aforementioned state of new somethingness, resulting from the being-towards-loss that she now inhabits and from the conscious anticipation of her brother's death —of the nothingness he will inescapably become. Paradoxically, hers is a form of somethingness that implies nothingness, inasmuch as, in her new situation of potential loss, while contemplating the sea near her grandmother's house, Helen herself imagines and fears such heart-rending nothingness. Overwhelmed by sadness, she feels tearful in view of the possibility that her brother will inevitably be reduced to a single memory that time will blur and eventually efface: Declan "soon [...] would only be a memory, and that too would fade with time" (46).

However, Declan's facticity does not count as the sole reason for Helen's entry into the transcendental domain of the mysterious: other consequential questions also intervene and entail her existential participation. After having visited her brother, she resumes her duties and attends an official meeting with the Irish Minister of Education, who recognises her as the daughter of one of his former colleagues, remembering him with fond admiration, awaking in her the bitter memories of her father's demise, and hence thwarting her attempt to reinstate normality by reverting to her professional activities. ${ }^{14}$ She is thrown - once againinto a truth event that, on this occasion, implies recalling the traumatic absence of her father, inescapably associating his death with Declan's destiny, and thereby doubling her feeling of loss in such a way that one may now view her as occupying a liminal space between two deaths or, rather, between two losses - her factual fatherlessness and her potential brotherlessness. Confronted with these two abysses, Helen crumbles: suddenly "she began to cry" (46) after her abrupt departure from the meeting.

As though her feelings of loss were not disruptive enough, Helen has to comply with Declan's request to contact their mother and grandmother in spite of all the time of distance and silence that she has thus far interposed between herself and her female relatives. In truth, such a request represents for Helen a formidable burden: it compels her to revisit her past, unbury painful memories, deal with her inner monsters, and redefine her traumas. One of these traumas may be understood as her psychological motherlessness. When Helen was only eleven years old, her parents went urgently to Dublin, leaving her and her brother in the care of her grandmother Dora. Several months passed without any letters or explanations. Nobody had the courage to tell Hellen and Declan why their parents had travelled to the capital indefinitely. All they knew was that their father needed to undergo some unspecific tests. This general secrecy made them feel abandoned, alienated from their family, and even anxious to run away from their grandmother's house. One day, without warning, their mother returned home in an unrecognisable shape: strange, distant, and lost. Her husband

${ }^{14}$ Later on, Helen makes yet another attempt to restore her previous protocols of life, but once again she does not succeed. The weighty, almost physical, and unbearable revelation of her brother's suffering and death interrupts her, detaches her from her work, and makes her realise - and feel- her state of thrownness and her being-toward-loss. This sudden realisation is described as follows:

Suddenly, the whole weight of what had happened and what was going to happen hit her as though for the first time: her brother was going to die, and they were going to watch him sicken further, suffer, and slowly fade. A vision came to her of his lifeless, inert body ready to be put in a coffin and consigned to darkness, closed away for all time. It was an unbearable idea. (104). 
had died of cancer and with him normality had also vanished. The familial union broke apart. Affection gave way to silence and resentment, especially in Helen's case. Unlike Declan, who managed to repair his relationship with his relatives perhaps due to his easygoing nature, his sister became utterly undemonstrative, withdrawn, and even hostile towards her mother and grandmother. This antagonism towards them is grounded, she reveals, in the feeling of unprotectedness (Ungeborgenheit) which germinated inside her after her father's death and intensified owing to the absence of emotional support from her closest women:

When my father died, my world collapsed, but I did not know this had happened. It was as though half my face had been blown away, and I kept talking and smiling, thinking that it had not happened, or that it would grow back. When my father died, I was left alone by my mother and grandmother. I know they had their own problems and maybe they could not have helped, maybe even the damage was already done, but I got no comfort or consolation from them. And these two women are the parts of myself that I have buried (187-8).

It follows from this excerpt - most especially, from the fact that Helen buried two of the most intrinsic parts of her Mitsein - that the loss of her father also rendered her motherless, grandmotherless, and hence acutely forlorn. Her first experience with death not only signified the physical and spiritual disappearance of her dear father, but it also caused her other psychological wounds or traumas: it isolated her, tripled her feeling of loss, destroyed her most intimate being-with-others, and polluted her familial sense of solicitude to such an extent that, in her unprotected and lonely state, she grew to "associate [...] love with loss" (188).

It is her mother, Lily, who attracts Helen's most fervid rancour. She felt not only abandoned and unloved, but also convinced that her mother bore the blame of everything concerning her father's passing. For some reason, in her pre-reflexive (mis)understanding of her parents' absence, ${ }^{15}$ Helen instinctively demonised her mother and thought that she had abandoned her and her brother with the deliberate intention of hiding her husband and remaining with him far from their children:

I've always believed that you took him away and you never brought him back. I know it's irrational, but that's what it was, that's what I felt. I thought that you had locked him away somewhere, that you knew where he was, that it was all your fault. Somewhere in the back of my mind, I believed all this (245).

In addition to such irrational theories, which were perhaps a product of her anxiety and loneliness in the face of her father's demise, Helen had further reasons for detaching herself from her mother and grandmother: both of them insistently tried to curtail her freedom, revoke her personal choices, and even impose their will on her professional life. In contrast with Declan, who was always granted the freedom to live and decide independently, Helen bumped into walls of familial oppression on several occasions. Once, for example, she was

${ }^{15}$ Helen's understanding of her father's death and the subsequent absence of her parents serves as an eloquent illustration of what Nikolas Kompridis (2006) terms first-order or pre-reflexive disclosure in the sense that such traumatic experiences were initially taken to mean deliberate actions of neglect and thus translated into preinterpreted intuitions and irrational perceptions which, although baseless and unilateral, developed into solid barriers between Helen and her mother. 
obliged to spend her summer holidays helping her grandmother to run her guesthouse at the expense of her wish to travel to America with her friends and boyfriend, who eventually deserted her. Much later, when she had started to work in Dublin, both her mother and grandmother did their utmost to persuade Helen, regardless of her own will, to quit her job in favour of a post at her town's religious school. Logically, in defence of her independence and indifferent to her family's dictates, she decided to stay in the capital, far from the women whom she had buried.

Nevertheless, in spite of its tragedy and fatality, Declan's limit situation —or, in particular, his nostalgic determination to conciliate his family at his grandmother's houseushers in a period of reconciliation. He seems to understand his own death as a catalyst for forgiveness and an opportunity to reassess the past with a view to paving the way for a future of familial union. At least it is Helen who interprets her brother's intentions in such terms: "I think," she says, "he felt that at a time like this we would all forget our differences" (98). As a matter of fact, Declan accomplishes his goal: his family reunites and starts to use "the language of emollience and reconciliation" (119). The process of fence-mending commences with the physical encounter of the whole family, which causes Helen to perceive the purgative potential of her critical situation and to feel strangely comfortable after all the years of mutism:

She realised that for the first time in years - ten years, maybe - she was back as a member of this family she had so determinedly tried to leave [...] the sense that they were once more a unit seemed utterly natural now there was a crisis, a catalyst. She was back home, where she had hoped she would never be again, and she felt, despite herself, almost relieved (106-7).

Her mother Lily also engages wholeheartedly in negotiating a renewed relationship with her daughter, revaluing her facticity with the benefit of hindsight, ${ }^{16}$ and opening herself to an inclusive form of truth that liberates her from her narrow vision of the past. When addressing her daughter, she adopts a "soothing voice and a tone of easy intimacy" (193), exhibits an attitude of "new softness" (193), feels free to express her "desolation and helplessness" (218), and lays bare a tender vulnerability that kindles Helen's sympathy. In this way, mother and daughter exchange their divergent views of what befell them after the loss they both suffered and notice that what precluded them from bridging their gaps was a problem of mutual misunderstanding or miscommunication. In the period of mourning for the death of the family's man, both Lily and Helen failed to identify and empathise with one another in spite of the manifest fact that their respective behaviours and reactions to their common loss were just identical: both of them became taciturn, solitary, and even impervious. However, these psychological similarities, instead of allying them in affective cooperation, grew into forces of inevitable friction. The simple logic of their reciprocal emotions rendered every

\footnotetext{
16 The idea of valuing one's facticity is central to Sartre's thought, for it saves and guarantees the existence and prevalence of freedom in spite of the weight of one's givens. The French thinker maintains that, regardless of the adversity and oppression of one's ineluctable circumstances, one is always free to appraise and judge them in a way that limits their influence to the magnitude one attributes to them (Michelman 2010:319). A clear case in point is the situation between Helen and her mother Lily: so pernicious were the values they used to ascribe to their common memories, that they ended up alienating one another until the outbreak of Declan's crisis, which now imposes a revaluation of the family's past.
} 
chance of contact impossible: since both of them were aloof, neither of them was able to replace such aloofness with an easy feeling of compassion.

Curiously enough, whilst the paternal and conjugal loss separated Helen and Lily, the certain potentiality of a second loss —of Declan's death - now has the opposite effect: it unites them and arouses in them the feeling of compassion they previously lacked. ${ }^{17} \mathrm{By}$ voicing out their bitter memories, disclosing sincere confessions, and engaging in heated arguments for the sake of eventual relief, both mother and daughter manage to put into practice what Kompridis (2006) would probably call receptive agency, i.e., the capacity to "become more attuned to our pre-reflexive understandings of the world, to our inherited ontologies, and to our historical circumstances, and thereby open up a freer relation to them" (202). In long and profound conversations, Helen and Lily listen closely to each other for the very first time: they share their personal judgements of the past, explain their unilateral understanding of their first common loss, discover the problem of mis-communication underlying their distance, re-examine their inherited ontologies together, debunk their irrational theories, ${ }^{18}$ and eventually clear their paths of past resentments in hopes of laying the foundations for a new, promising, and wholesome mother-daughter relationship.

Consequently, Helen recomposes and repairs her Mitsein. After a serious process of reflective disclosure, ${ }^{19}$ she reincorporates her mother into her intersubjective sphere, singing a song along with her in token of reconciliation and promising her a future of fluent communication. With her grandmother the differences are also settled: as if by domino effect, the peace Helen reaches with her mother extends collaterally to her grandmother, whom she now describes as being "all charm" (198). It appears that in neither case —neither against Lily nor against her grandmother- does Helen's rancour prove to be reasonable or sustainable anymore. The crisis of her brother's potential demise has served the - paradoxically auspicious - purpose of bringing the family together, toppling the rule of silence, creating a framework for curative dialogue, venting and healing old traumas, revisiting the past with the illuminating help of the Other, and opening the doors to a future of familial understanding and love.

A sacrifice is at stake, though. ${ }^{20}$ While Helen is mending fences and reconciling with her mother and grandmother, Declan is writhing in agony, suffering dreadful nightmares, bursting into cries of pain, losing his body, and asking for maternal help. His sister foresees

${ }^{17}$ In his review of the novel, Terry Eagleton (1999) also takes notice of this contrast and expresses it in a laconic and precise manner: "It was the death of Helen's father which turned her against her mother, and it takes another death to reunite them."

${ }^{18}$ As I have formerly explained, in her pre-reflexive understanding of her father's death, Helen vilified her mother and accused her not only of having abandoned her and her brother, but also of having supposedly "locked him [her father] away somewhere" (245), knowing where he was and purposely depriving her children of their right to be with him. It is such irrational accusations that Helen rethinks and rectifies in a cathartic dialogue with her mother.

19 By this concept Nicolas Kompridis (2006) denotes the "ways in which [...] background structures of intelligibility are reopened and transformed through novel interpretations" (34). In Helen's case, she reinterprets the meaning of her memories, reopens herself to her family, overcomes the limitations of her intersubjectivity, inaugurates a new beginning with her closest relatives, "clears the way and liberates" (67) herself from her past resentments.

${ }^{20}$ I make deliberate use of the word sacrifice in keeping with Terry Eagleton (1999), who insightfully interprets Declan's death "as a kind of blood sacrifice to re-cement familial bonds." 
and feels his quietus with "a hardness in her heart against the world" (259). Contemplating the immutable and resolute course of the sea, she comes - as though she were a full-blown existentialist - to the realisation that nothing matters objectively, that nature is careless and indifferent to human suffering or love, and that the world has no needs of its own, no preferences, and no inherent values:

It was clear to her now, as though all week had been leading up to the realisation, that there is no need for people, that it did not matter whether there were people or not. The world would go on. The virus that was destroying Declan, that had him calling out helplessly now in the dawn, or the memories and echoes that came to her in her grandmother's house, or the love for her family she could not summon up, these were nothing, and now, as she stood at the edge of the cliff, they seemed like nothing (260). ${ }^{21}$

The nothingness Helen fears and predicts is now imminent. After having spent a long week of familial reunion at his grandmother's house, Declan sinks into such a state of frailty, that he has to return to hospital. On his way back to Dublin, his mother and sister sing a children's song to tranquillise him in an eloquent scene - or picture- which captures the core concerns of Tóibín's novel and which one may call thusly: the recovery of familial love in the face of loss. At the end of the story, Declan is left to die in hospital and Helen invites her mother to her house for the very first time.

\section{CONCLUDING REMARKS}

The foregoing study perspicuously reveals that Colm Tóibín's The Blackwater Lightship constitutes a profoundly existential novel for a primary reason: its protagonist, Helen O'Doherty, experiences a genuine moment of truth which triggers a long concatenation of momentous events. Her inauthentic normality crumbles. Her usual protocols of life expire. Her previous positivistic perception of death is superseded by a personalised vision of her potential brotherlessness. Her problem-solving logic becomes unavailing. Her feet land in a painful state of Geworfenheit. Her steps take the direction of what Stolorow calls a being-toward-loss. Her limit situation —or Grenzsituation — causes her to dream of a de-authenticated condition

${ }^{21}$ So patently existential is this excerpt, that it readily catapults me to a fragment from Sartre's Nausea (1938), where Anton Roquentin, the main character, contemplates the root of a tree and muses on the superfluity, futility, absurdity and indifference of the world. The passage, although somewhat long, is worth quoting on account of its manifest connection with Helen's reflection:

There we were, the whole lot of us, awkward, embarrassed by our own existence, having no reason to be here rather than there; confused, vaguely restless, feeling superfluous to one another. Superfluity was the only relationship I could establish between these trees, these hedges, these paths. Vainly I strove to compute the number of the chestnut trees, or their distance from the Velleda, or their height as compared with that of the plane trees; each of them escaped from the pattern I made for it, overflowed from it or withdrew. And I too among them, vile, languorous, obscene, chewing the cud of my thoughts, I too was superfluous. [I is you or I or anyone.] Luckily I did not feel it, I only understood it, but I felt uncomfortable because I was afraid of feeling it... I thought vaguely of doing away with myself, to do away with at least one of these superfluous existences. But my death - my corpse, my blood poured out on this gravel, among these plants, in this smiling garden- would have been superfluous as well. I was superfluous to all eternity (in Flynn 2006:58-59). 
of Geborgenheit, to envy the position of an imaginary numb otherness, and to momentarily adopt an attitude of bad faith. However, she has no way back into her previous impersonal everydayness: with the outbreak of her brother's crisis, she is made to cross the threshold of the mysterious sphere of human existence, to acknowledge her new state of Unheimlichkeit, and even to grapple with her traumatic memories of the past. Her fatherlessness re-emerges and exacerbates her deep-rooted feeling of loss. The resentments against her mother and grandmother reappear to be reflectively disclosed, negotiated, and purged with receptive agency and emotional openness. Yet, the eventual reconciliation between Helen and her closest women entails her brother's sacrifice. It is the threat — and inevitability — of Declan's death that motivates his family's reunion and recovery of love.

The claim that The Blackwater Lightship constitutes an existential text proves reasonable and cogent in view of how easily it lends itself to a close dialogue with Martin Heidegger, Jean Sartre or Gabriel Marcel, whose tenets and precepts yield deep insights into the philosophical issues Colm Tóibín fictionalises in the novel I have scrutinised in this paper. However, I cannot help but wonder whether such a close dialogue could be extended to the other works that the Irish writer has produced. Would Heidegger continue to be of use in exploring them? Would they converse readily and fruitfully with Sartre? Or would they repel existentialism altogether and circumscribe it to the confines of The Blackwater Lightship? Obviously, the answers to these questions go well beyond the scope of the present article, albeit with the certainty that they will have their own spaces of analysis and discussion in my future research projects.

\section{WORKS CITED}

CANNING, Richard (1999): Review for The Independent, quoted in the reprinted edition of The Blackwater Lightship (2008).

Carregal-Romero, José (2012): “Colm Tóibín and Post-Nationalist Ireland: Redefining Family through Alterity." Estudios Irlandeses 7, pp. 1-9.

Costello-Sullivan, Kathleen (2012): Mother/Country: Politics of the Personal in the Fiction of Colm Tóibín. Bern: Peter Lang.

Critchley, Simon (2002): "Enigma Variations: An Interpretation of Heidegger's Sein und Zeit." Ratio: An International Journal of Analytic Philosophy, 15.2, pp. 154-175.

Delaney, Paul (2008): Reading Colm Tóibín. Dublin: Liffey Press.

Eagleton, Terry (1999): "Mothering." London Review of Books. 14 October. http://www.lrb.co.uk/ v21/n20/terryeagleton/mothering [20/04/2015].

Flynn, Thomas R. (2006): Existentialism: A Very Short Introduction. New York: Oxford University Press.

Gray, Glenn J. (1951): “The Idea of Death in Existentialism.” The Journal of Philosophy, 48.5, pp. 113-127.

Harte, Liam (2010): “The Endless Mutation of the Shore: Colm Tóibín's Marine Imaginary.” Critique: Studies in Contemporary Fiction, 51. 4, pp. 333-349.

Kompridis, Nikolas (2006): Critique and Disclosure: Critical Theory between past and Future. Cambridge, MA: MIT Press.

Luchte, James (2008): Heidegger's Early Philosophy: The Phenomenology of Ecstatic Temporality. London: Continuum. 
Marcel, Gabriel (1965 [1949]): Being and Having: An Existential Diary. Trans. Katherine Farrer. New York: Harper \& Row.

Matthew, Ryan (2008): "Abstract homes: deterritorialisation and reterritorialisation in the work of Colm Tóibín.” Irish Studies Review, 16.1, pp. 19-32.

Michelman, Stephen (2010): The A to Z of Existentialism. Lanham: Scarecrow Press.

O’Callaghan, Paul (2009): “Gabriel Marcel” Philosophica: Enciclopedia Filosófica Online. http:// www.philosophica.info/archivo/2009/voces/marcel/Marcel.html [25/04/2015].

Sweetman, Brendan (1995): "Gabriel Marcel and the Problem of Knowledge." Bulletin de la Société Américaine de Philosophie de Langue Française, 7.1/2, pp. 148-163.

Stolorow, Robert D. (2011): World, Affectivity, Trauma: Heidegger and Post-Cartesian Psychoanalysis. New York: Routledge.

- (2014): "Love, Loss, and Finitude." Janus Head: Journal of Interdisciplinary Studies in Literature, Continental Philosophy, Phenomenological Psychology, and the Arts, 13.2, pp. 35-44.

TóiBín, CoLm (1999 [2008]): The Blackwater Lightship. London: Picador.

Treanor, Brian (2010): “Gabriel (-Honoré) Marcel”, The Stanford Encyclopedia of Philosophy (Winter 2014 Edition), Edward N. Zalta (Ed.) http://plato.stanford.edu/archives/win2014/ entrieentries/marcel/ [18/04/2015].

Walshe, EibHear (2013): A Different Story The Fictions of Colm Tóibín. Dublin: Irish Academic Press.

- (2008): “This particular Genie': The Elusive Gay Male Body in Tóibín's Novels”, in Delaney, Paul (Ed.). Reading Colm Tóibín. Dublin: The Liffey Press. 115-130.

Waterman, Rory (2012): “Colm Tóibín” British Council Literature. http://literature.britishcouncil. org/colm-taiban [30/04/2015].

Yebra, José M. (2014): “The Interstitial Status of Irish Gayness in Colm Tóibín's The Blackwater Lightship and The Master." Estudios Irlandeses 9, pp. 96-106. 